\title{
TECHNICAL LITERACY OF ELEMENTARY SCHOOL PUPILS, STATUS AND PERSONALITY OF TECHNICAL SUBJECTS TEACHER
}

Patrik JANÍČ EK*, Univerzita Konštantína Filozofa v Nitre, Slovenská republika

Jana DEPEŠOVÁ, Univerzita Konštantína Filozofa v Nitre, Slovenská republika

Přijato: 2. 12. 2019 / Akceptováno: 8. 4. 2020

Typ článku: Teoretická studie

DOI: $10.5507 /$ jtie.2020.006

Abstract: The current company is characterized by the use of modern technologies, informatics and upcoming robotics and automation. As a result, technology has spread to all areas of human life and work. It is desirable for the pupil to have technical education, to use the acquired knowledge in the field of machine operation, material processing, physical and chemical properties of individual types of material. Modern technical time requires active computer work. Teaching the subject of technology at elementary school is provided by a knowledgeable teacher with technical education.

Key words: technology, pupil, teacher, school, education.

\section{TECHNICKÁ GRAMOTNOSŤ ŽIAKA ZÁKLADNEJ ŠKOLY, STATUS A OSOBNOSŤ UČITELA TECHNICKÝCH PREDMETOV}

Abstrakt: Súčasná spoločnost' je charakterizovaná využivaním moderných technológií, informatiky a nastupujúcej robotizácie a automatizácie. Vd'aka čomu sa technika rozširila do všetkých oblastí l'udského života a pracovných činnosti. Je žiaduce, aby žiak disponoval technickým vzdelávaním, využival nadobudnuté vedomosti zoblasti fungovania strojov, spracovania materiálov, fyzikálnych a chemických vlastnosti jednotlivých druhov materiálu. Moderná technická doba si vyžaduje aktívnu prácu s počítačom. Vyučovanie predmetu technika na Základnej škole zabezpečuje erudovaný učitel's technickým vzdelaním.

Klíčová slova: technika, žiak, učitel', škola, vzdelanie.

\footnotetext{
*Autor pro korespondenci: patrik.janicek@ukf.sk
} 


\section{1 Úvod}

V dôsledku spoločenských a politických zmien sa musel školský systém Slovenskej republiky po roku 1990 zmenit'. Na základe spolupráce s inými krajinami, nastupujúcim pokrokom vedy a techniky a odporúčaním Európskeho parlamentu bolo potrebné formovat' vzdelanostnú spoločnost'. S technickým vzdelávaním je spätý život človeka neustále. Dôležitost' využívania trvalých vedomosti z oblasti techniky využívaných pri bežných činnostiach a práci je viditel'ný. Význam technického vzdelávania nevychádza len z potrieb Slovenskej republiky, ale význam je celosvetový. Možno sa aj my dostaneme do úrovne akú majú v Japonsku, kde pokladajú technické vzdelávanie za významný prvok vo vzdelávacom systéme. Na zlepšenie aktuálneho stavu sa inovoval Štátny vzdelávací program.

\section{Použité metódy}

V d'alších častiach príspevku sme použili teoretické metódy pedagogického výskumu, najmä literárnu metódu. Extrahovali sme a spracovali informácie z dostupných zdrojov. Išlo o uvedené zdroje, odporúčania a analýzy. Pri vyhodnocovaní informácí́ sme sledovali stav technického vzdelávania v minulosti a po následných zmenách implementovaním IŠVP.

\section{História technického vzdelávania}

Slovenská republika má bohatú históriu technického vzdelávania na školách. Už v období Rakúsko-Uhorskej monarchie sa s vel'kým zanietením budovali prvotné snahy o vznik učňovského vzdelávania a učňovských škôl zameraných hlavne na segment pol'nohospodárstva. Snaha o lepšie rozčlenenie učňovského vzdelávania prišla začiatkom 20.storočia kedy sa obsah vzdelávania mení v meštianskych školách. Nastáva obdobie tvorby učňovského vzdelávania. Po vzniku Československej republiky sa zjednotili školské systémy a do škôl sa zavádzajú ručné práce. V období 2. svetovej vojny sa vyslovujú myšlienky o absencii technického vzdelávania na školách. Chýba výučba techniky v spojení s prírodovednými predmetmi (Lukáčová \& Bánesz, 2007). Naše školstvo sa začalo zaoberat' myšlienkou aplikovania polytechnického vzdelávania $v$ nadväznosti na spojenie techniky a praxe s významom prehíbenia si už získaných základných vedomosti z technických a prírodných vied, tým sa docielila výchova mladých robotníkov. Inovácia vzdelávania nastala po roku 1990. Politické zmeny a dostupnost' nových informácií a technológií zmenili život človeka v modernej technickej spoločnosti. Vychádzame z odporúčania Európskej únie, ktoré Kozík, Depešová zhodnotili ako potrebné k budovaniu technickej gramotnosti a to tak, že na základe odporúčania je vhodné, aby každý jedinec $\mathrm{v}$ rámci celoživotného vzdelávania si najskôr získal, následne osvojil základy techniky, konštrukčných princípov a poznal dôsledky techniky na jeho život a životné prostredie. Jednoducho, aby získal potrebné vedomosti, ktoré označujeme termínom technická gramotnost' (Kozík \& Depešová, 2007). Pojem technickú gramotnost' chceli definovat' viacerí autori ako u nás aj v zahraničí a to hlavne Dyrenfurth, Toldsepp a Zoller. V Slovenskej republike sa uvedenou problematikou zaoberali okrem spomínaných autorov aj Krušpán, Pavelka a Kožuchová. Rozvoj školstva na území Slovenskej republiky súvisí aj s transformáciou vzdelávania a výchovy žiakov, ktorý je poznačený aj zmenami v oblasti smerovania vzdelávania. Politická situácia mala za následok v období po roku 1989 iné vnímanie ideológie nášho školstva a vzdelávania. Roky plynuli a snaha 
zmenit' systém vzdelávania a jeho inováciu priniesol projekt MILÉNIUM. V predmete technika bola inovácia hned' v názve. V roku 2008 sa upustilo od označenia technická výchova. Ďalšou zmenou bolo zníženie vyučovacích hodín v predmete. Praxou sa zistilo, že nastolený stav počtu vyučovacích hodín nie je postačujúci a bolo potrebné vykonat' zmeny. Tie sa udiali v roku 2013 s návrhom Štátneho vzdelávacieho programu. Pozitívne tu vnímame zvýšenie časovej dotácie vyučovacích hodín pre predmet technika. Inovovaný Štátny vzdelávací program MŠVVaŠ SR bol predstavený pod označením 2015-5129/5980:2-10A0 s platnost'ou od septembra 2015. Škola je $\mathrm{v}$ súčasnej dobe povinná odučit' $\mathrm{z}$ tematického okruhu Technika najmenej dve tretiny $\mathrm{z}$ celkovej časovej dotácie vyučovacieho predmetu v každom školskom roku a najviac jednu tretinu $\mathrm{z}$ celkovej časovej dotácie vyučovacieho predmetu $\mathrm{v}$ školskom roku z tematického okruhu Ekonomika domácnosti podl’a svojich materiálno-technických a personálnych podmienok. Ak chceme hovorit' o úspešnosti vzdelávania $\mathrm{v}$ predmete technika tak implementovanie inovovaného obsahu technického vzdelávania je úlohou pedagóga, riaditela školy, MŠVVaŠ SR a v neposlednom rade aj rodičov žiakov (ŠPÚ, 2015). Predmet technika sa obsahovo odlišuje v jednotlivých krajinách. Z pohl'adu globálneho je obsah predmetu koncipovaný tak, aby bolo zabezpečené nadobudnutie technickej gramotnosti v modernej európskej a informačnej spoločnosti.

\section{Význam technického vzdelávania}

Význam technického vzdelávania na základných školách je opodstatnený. Slovenská republika ako člen Európskej únie prijala názor, že je potrebné mat' v primárnom vzdelávaní taký predmet, pomocou ktorého edukanti nadobudnú také vedomosti a získajú tie zručnosti, ktoré sú nápomocné v orientácií v technike. Získané vedomosti im pomôžu $\mathrm{k}$ implementácí sa do modernej technickej spoločnosti ako plnohodnotne vzdelaný občan štátu. Popud k získavaniu technického vzdelávania je zrkadlom toho, že technika a nástup nových moderných technológií preniká do každej sféry života. Môžeme povedat', že nosnými piliermi predmetu technika sú ciele zamerané na:

- naučenie žiakov vyrábat' technické produkty,

- naučenie žiakov manipulácii a obsluhovaní technických prostriedkov,

- naučenie žiakov $\mathrm{k}$ vysloveniu vlastných názorov o možnosti využívania techniky v bežnom živote a jej dopade na životné prostredie a spoločnost',

- naučenie žiakov využívat' a pracovat' s osobným počítačom(Kožuchová \& Pavelka, 2007).

Jednotlivé čiastkové ciele sa zameriavajú na získavanie vlastnej skúsenosti z merania, čítania technických výkresov a zobrazovania. Rozoznávania špeciálnych technických symbolov, značiek a algoritmov. V neposlednom rade získat' skúsenosti prácou s materiálom a využívat' pri práci technické stroje a zariadenia a vediet' s nimi pracovat'. Pri práci dokázat' vyslovit' svoj názor na výrobu daného produktu, zdôvodnit' jeho význam a dopad na životné prostredie. Nie všetky technické činnosti sa dajú využívat' bez znalosti osobného počítača. Ten sa $v$ technickom vzdelávaní využíva na jednoduché, ale aj náročné pracovné operácie. Pomáha pri vytváraní návrhov modelov až po výrobu jednotlivých súčasti technických výrobkov. Už počas prvých rokoch na základnej škole sa žiaci stretávajú okrem praktických technických predmetov označovaných ako praktická výchova, technika a pod. aj s technológiami, 
s ktorými pracujú. Využívajú modernú techniku a aplikácie na zlepšenie úrovne a spôsobu vyučovania. V inovovanom vzdelávaní sa $\mathrm{v}$ školách zriad'ujú tabletové triedy, zavádza sa systém elektronických triednych kníh, stravovanie v škole sa objednáva on line a mnoho malých krokov z nášho pohl’adu, ale pre žiaka základnej školy ide o novinky. Napriek tomu žiaci bežne doma využívajú pripojene na rôzne sociálne siete, využivajú inteligentné mobilné telefóny. Vel'ké množstvo rozvinutých krajín vníma význam predmetu technika (technology) ako potrebný pre rozvoj žiaka, ale nie je považovaný za akademický predmet $s$ jednoznačne definovanou štruktúrou. Kurikulum základného technického vzdelania vychádza z koncepcie návrhu Sterryho (1987) pozostávajúceho $\mathrm{z}$ dvoch úrovní prepojených na základné vzdelávanie a všeobecné stredoškolské vzdelávanie. $\mathrm{Na}$ základe kvalitnej a odbornej prepracovanosti ju UNESCO v 20. storočí odporučilo všetkým členským krajinám ako vhodnú na implementáciu do svojich kurikulárnych dokumentov(Kožuchová, 1993). Polemika o významnosti technického vzdelávania a opodstatnenosti technických predmetov v našom vzdelávacom systéme rozpracovali Kozík, Lukáčová a Kuna v odbornom príspevku s podporou grantovej agentúry KEGA 021UKF-4/2014. Na základe zistení opisujú význam technického vzdelávania ako významný prostriedok v edukácií tým, že:

- technické predmety podporujú technickú priestorovú orientáciu,

- rozvíjajú tvorivé, technologické, technické a konštruktérske myslenie,

- podporujú pochopenie prírodovedných poznatkov,

- podporujú orientačno-komerčné myslenie,

- pomáhajú osvojovaniu návykov a zručností používat' technické pomôcky,

- sa podiel'ajú na schopnosti tímového a kooperatívneho vyučovania v súvislosti na experimentálne činnosti vo sfére tvorby technických produktov,

- pomáhajú $\mathrm{k}$ efektívnemu mysleniu žiakov, ich práci $\mathrm{s}$ technológiami, prístrojmi, pomôckami a materiálom(Kozík \& Lukáčová \& Kuna, 2016).

Rozdielnost' technického vzdelávania vo svete a krajinách EÚ sa venuje rastúca pozornost'. Vidiet' to $\mathrm{v}$ prijímaných dokumentoch Európskeho parlamentu a Rady Európy, ako aj z výsledkov monitorovacích správ. Predmety technického zamerania sa zarad’ujú do učebných plánoch na rôznych stupňoch vzdelávania primárneho, ale aj sekundárneho s rôznou časovou dotáciou vyučovacích hodín. Obsah predmetov sa v jednotlivých štátoch vzájomne liši, pričom je vo všeobecnosti zameraný na nadobúdanie technickej gramotnosti. V zmene technického vzdelávania pristupujú jednotlivé krajiny odlišne. Majú rôzny počet tematických celkov, ich zameranie a rozdielnost' nájdeme aj časovej dotácii. Ak by sme chceli vzájomne komparovat' obsah predmetov technického vzdelávania bolo by to zložité nakol'ko v jednotlivých krajinách má predmet technika rôzny počet tematických celkov a rozdielnu časovú dotáciu. Časová dotácia pre predmet technika je na Slovensku v rozsahu 33 hodín ročne, čo v období ročníkov 5. až 9. predstavuje dotáciu 165 vyučovacích hodín pre technické vzdelávanie. V niektorých krajinách Európskej únie je vymedzená časová dotácia pre technické vzdelávanie v nižšom strednom vzdelávaní až 400 vyučovacích hodín(Stebila, 2016). Hodinová dotácia pre technické vzdelávanie je na Slovensku definovaná v Rámcových učebných plánoch pre základné školy, ktoré upravilo 
MŠVVaŠ SR, kde uvádza poznámku, že zo vzdelávacieho štandardu predmetu Technika vyplývajú limity vzájomného pomeru časových dotácií oboch tematických okruhov, t. j. pri 33 hodinách ročne môže škola vyučovat' minimálne 22 hodín v rámci okruhu Technika a maximálne 11 hodín v rámci okruhu Ekonomika domácnosti. Pritom platí, že počet hodín okruhu Ekonomika domácnosti môže klesat' (naopak, počet hodín Technika môže stúpat'). My s uvedenými argumentmi súhlasíme a dopíňame, že opísané skutočnosti boli impulzom pre zmeny v štátnom vzdelávacom programe v roku 2015 a následným Inovovaným štátnym vzdelávacím programom, kde už významným prvkom bolo navýšenie vyučovacích hodín v rámci technického vzdelávania primárneho a sekundárneho stupňa. $\mathrm{Na}$ záver môžeme dodat' slová Kozíka, ktorý tvrdí, že: „z hl’adiska rozvoja sebaobslužných aktivít má výučba techniky vo výchovnom programe základnej školy svoje nezastupitel'né miesto" (Kozík \& kol., s. 25). Znovuobjavenie čara technických predmetov u žiakov môže byt' ich budúcou cestou, ktorá nám pomôže oživit', zachovat' a následne rozvíjat' v budúcnosti odborné technické povolania. Technické vzdelávanie má svoje nezastupitel’né miesto v systéme vzdelávania hlavne preto, že:

- technické vzdelávanie je žiaduce a preto je vhodné, aby sa s ním začalo už v mladom veku detí,

- je nevyhnutné docielit' spoločenské uznanie technického vzdelávania ako významného faktora dlhodobého rozvoja spoločnosti,

- na základe odporúčaní Európskeho parlamentu a Rady o klúčových kompetenciách pre celoživotné vzdelávanie sa majú začleňovat' predmety s technickým smerovaním do sústavy predmetov,

- vyučovanie na základných školách by malo byt' zamerané na získavanie technickej gramotnosti jednotlivca $v$ informačnej spoločnosti a to $\mathrm{v}$ oblastiach: materiály a základné technológie ich spracovania, ekológia a technika, princípy a systémy technických zariadení, environmentálne aspekty l'udského bytia, zdravie a bezpečnost' pri práci, práce v domácnosti, ekonomika domácnosti, práca s počítačom.

- l'udský kapitál je klúčovým činitel’om hospodárskeho rozvoja krajiny. Je potrebné vytvárat' podmienky a motiváciu pre technicky talentovanú mládež, aby mohla uplatnit' a rozvíjat' svoj talent v zmysluplnej práci (Dubovská \& Polčic, 2004).

\section{Učitel' techniky a jeho osobnost'}

Status predstavuje spoločenské postavenie alebo úctu, ktorú požíva učitel'stvo v súvislosti so stupňom uznávania dôležitosti jeho funkcie a schopnosti plnit' ju (Samuhelová \& Tokárová, 1996). Statusom v učitel'skej profesii sa zaoberal aj Ondrejkovič, ktorý status rozdel'uje na vrodený, ktorý je daný predovšetkým pohlavím učitel'ov. Autor zdôrazňuje, že sociálny status učitel’ov a učiteliek je odlišný ako aj ich správanie. Domnieva sa, že učitel' je na pracovisku vyššie, z dôvodu feminizácie školstva a naopak, že v spoločnosti bude postavenie učitel'a v porovnaní s učitel'kou nižšie. Ďalej opisuje získaný status, ktorý si učitel' získava vlastným úsilím, prostredníctvom vlastného výkonu. Posledným statusom je nanútený, ide o špecifický prípad pripísaného statusu a týka sa extrémnych situácií, v ktorých sa môžu učitelia ocitnút' (spájanie a zatváranie škôl, dochádzka do zamestnania). Ondrejkovič vysvetl'uje možnú súvislost' medzi statusom a postavením učitel'ov v spoločnosti, 
pričom predpokladá, že postavenie učitel'ov $\mathrm{v}$ našej spoločnosti je ovplyvnené všetkými tromi uvedenými charakteristikami statusov. Moderný učitel' by mal vystupovat' ako vyrovnaná osobnost'(Ondrejkovič, 2003). Pri snahe o presnú definíciu práce učitel'a môžeme vychádzat' $\mathrm{z}$ rôznych názorov, pohl'adov odborníkov $\mathrm{v}$ oblasti psychológie, pedagogiky a didaktiky. V širšom zmysle sú uvedené definície totožné. Pozorovat' môžeme len subjektívny názor pri definícii učitel'a. Učitel'stvom sa zaoberá veda nazývaná pedeutológia. Ďuričková opisuje ako by sme mali k problematike učitel'stva pristupovat'. Pri charakterizovaní statusu učitel'a rozlišuje dve hl'adiská. Analytické a normatívne pri ktorom hl'adáme odpovede na otázky. Aký má byt' učitel'? $\mathrm{Na}$ rozdiel od analytického hl'adiska zastrešujúce vlastnosti pedagóga(Duričková, 1998). Učitel’ov charakterizujeme ako pedagogických pracovníkov, ktorí sa venujú výchove a vzdelávaniu. Ide o pracovníkov garantujúcich kvalitu výchovy a vzdelávania ako aktívnych činitel'ov úspešnosti vzdelávacieho procesu. Opisujeme ich aj ako sprievodcu v živote žiaka, ktorý ho vedie $\mathrm{k}$ múdrosti a $\mathrm{k}$ poznaniu. Často ich označujeme aj ako idealistov, večných študentov(Pajtinka, 2006). Postavenie v práci je širokospektrálne a majú rôzne pracovné úlohy. My uvádzame hlavné postavenie úloh pedagóga v škole podl'a Č́ápa a doplnené podl'a Duričekovej. Ide o postavenie vychovávatel'a žiaka a celej sociálnej skupiny v ktorej je začlenený. Učitel' musí v celej triede formovat' presvedčenia, charakter a postoje žiakov. Nel'ahkou úlohou je vyučovat' a vzdelávat' žiakov a kreovat' celý vyučovací proces v osvojovaní si nových a potrebných vedomosti, praktických zručností a návykov. Neustály kontakt so žiakmi sa odzrkadl'uje aj na formovaní si vzt’ahov s nimi. Formovanie pozitívnej klímy a vzájomných vzt’ahov vytvára predpoklady k úspešnému zvládaniu potrieb vyučovania. Neodmyslitel'nou potrebou je snaha učitel’a o neustále sa vzdelávanie vo svojom odbore. Pri vyučovaní je žiaduce, aby mal učitel' osvojené potrebné psychologické a pedagogické poznatky a spôsoby, metódy myslenia, ktoré efektívne vplývajú na jeho prácu. V pedagogickej praxi učitel' pôsobí v škole a jeho vplyv sa odzrkadl'uje aj na mimoškolskom vyučovaní a preto je prospešné, aby učitel' dával žiakom pozitívny príklad v správaní. Úlohy v práci učitel'a je potrebné chápat' komplexne, pričom za prioritné považujeme nielen úlohy orientované na výchovno-vzdelávacie procesy, ale aj na činnosti zamerané na vývoj a sebazdokonal'ovanie osobnosti edukátora so zretel'om na sociálnu stránku. Na základe toho môžeme konštatovat', že predmetné úlohy učitel'a sú rovnocenné, vzájomne sa ovplyvňujúce a integrujúce do jedného celku (Pajtinka, 2006). Charakteristika osobnosti je vel'mi komplexná. Osobnost' edukátora je značnou mierou ovplyvnená osobnost'ou človeka, jeho životom, skúsenost’ami a zážitkami, ktoré prežil. Uvedieme definíciu kolektívu autorov Ďuriča a Bratskej, ktorí sa zhodujú v charakterizovaní osobnosti ako:

„komplexu vlastností, ktoré jednotlivec získal v predmetnej činnosti a styku a ktoré ho charakterizujú z hl'adiska účasti na spoločenských kontaktoch. Je to vlastne organizovaný a najvyšší celok duševného života človeka, ktorý reguluje správanie“ (Durič \& Bratská a kol., 1997, s. 211).

Osobnost' sa prejavuje ako jednotný a harmonický celok, ale v realite je spojením viacerých protikladov, ako rozumu a citu, pudov a vôle, vnímania a fantázie. Jednotlivé osobnosti sa navzájom odlišujú na základe genetiky, ale aj vo vlastnostiach, ktoré získali v priebehu života (Ďurič \& Bratská a kol., 1997). Učitel’ova 
osobnost' je teda jedným z najdôležitejším determinantom vzdelávacej činnosti podiel'ajúca sa na úspechu vzdelávania. Je opodstatnené, že na prácu učitel’a sa kladú aj v 21. storočí vysoké nároky. Existuje množstvo odborných teórií, názorov žiakov a rodičov aký má byt' učitel. V odbornej pedagogickej literatúre sa stretávame s názorom, že učitel' by mal mat' zodpovedajúce kvalitné odborné vzdelanie, ideálnu psychologickú a metodologickú prípravu a v neposlednom rade požadované vlastnosti. Je žiaduce, aby odborná príprava učitel'a presahovala hranice učebnej látky ktorú exponuje edukátorom počas vyučovacieho procesu. Rozsiahlejšia miera všeobecného vzdelania zabezpečí pedagógovi lepšiu a l'ahšiu cestu na budovanie priatel'ských vztahov so žiakmi aj mimo vyučovacieho procesu v kompozícií s pedagogickým taktom, ktorý pomôže k pochopeniu vnútorného sveta žiaka a jeho duševného života. Naše tvrdenia dokazujú uvedené názory autorov, že:

„učitel' má disponovat' primeranými teoretickými a odbornými poznatkami $\mathrm{z}$ viacerých oblastí a mal by mat:

- odborné vedomosti z predmetov, ktoré vyučuje,

- odborné vedomosti týkajúce sa vývinových charakteristík žiakov,

- poznatky a vedomosti týkajúce sa organizácie vyučovacej hodiny,

- poznatky z oblasti didaktiky,

- primerane rozvinuté jazykové a rečové schopnosti,

- poznatky z oblasti hodnotenia(Višňovský \& Kačáni a kol., 2000, s. 61).

Z uvedeného vieme dedukovat', že poznatky je potrebné získat' vysokoškolskou prípravou vo vzájomnom prepojení s charakteristikou osobnosti pedagóga. Ak dokážeme vytvorit' optimálne podmienky pre vyučovanie s kvalitne pripraveným učitel'om tak docielime to, že žiaci po absolvovaní predmetu technika:

- získajú lepšie zručnosti pri práci s výpočtovou technikou, ktoré im pomôžu zvládat' bežné činnosti,

- na základe historického exkurzu do dejín techniky získajú vyššiu úroveň vnímania a pochopenia prírodných vied,

- získajú poznatky a vedomosti o jednotlivých procesoch výroby a výrobných profesiách,

- porozumejú významu výskumu v oblasti techniky pre rozvoj spoločnosti,

- dokážu vyhodnotit’ technologické procesy(Kozík, 2013).

Výsledným produktom vzdelávania žiaka by mal byt' pripravený človek, ktorý sa bude nad'alej vzdelávat' a učit' sa. Mal by byt' pripravený sa adaptovat' na život v modernej spoločnosti.

\section{Záver}

Vyučovanie Techniky na Základnej škole vedie žiakov k získaniu základných užívatel'ských zručností v rôznych oblastiach l'udskej činnosti. Skladba predmetu vychádza z konkrétnych životných situácií s ktorými žiak prichádza do kontaktu. Vyučovanie techniky musí byt' založené predovšetkým na praktickej činnosti, náplň sa cielene zameriava na zručnosti a návyky pre uplatnenie žiakov $\mathrm{v}$ d’alšom živote v spoločnosti. Technické vzdelávanie malo nastavený dobrý smer. Zmeny, ktoré sa 
udiali ho spomalili a zamedzili atraktívnosti technických povolaní u žiakov. Čo malo za následok istý nezáujem o vykonávanie technických prác budúcich absolventov. Inovovaný Štátny vzdelávací program by mal zabezpečit budúcim generáciám zvýšený záujem o technické predmety. Je potrebné reagovat' na potreby pracovného trhu a zabezpečit', aby uvedený predmet vyučovali učitelia, ktorí majú nie len vzt'ah $\mathrm{k}$ žiakom, ale aj $\mathrm{k}$ technike a dokážu žiakom sprostredkovat' všetky potrebné informácie.

\section{Literatúra}

Dubovská, R., \& Polčic, L. (2004). Technická a pracovná výchova po roku 1989. In T. Kozík, a kol., Technické vzdelávanie v informačnej spoločnosti. Nitra: PF UKF. Ďuričková, M. (1998). Psychológia žiaka a učitel'a. Prešov: Prešovská univerzita. Durič, L., \& Bratská. M. a kol. (1997). Pedagogická psychológia Terminologický a výkladový slovník 5. zväzok. Bratislava: SPN.

Kozík, T., \& Depešová J. (2007). Technická výchova v Slovenskej republike v kontexte vzdelávania v krajinách Európskej únie. Nitra: PF UKF.

Kozík, T. (2013). Je opodstatnené vyučovat' techniku na základnej škole? In Technical, Human and Social Sciences: Is it Possible to Dialogue in the Pedagogical Process? (1-12). Praha: ČVUT.

Kozík, T., \& Lukáčová, D., \& Kuna P. (2016). Úloha technického vzdelávania v spoločnosti. Edukacja-Technika-Informatyka, 2 (16), 114-120.

Kozík, T. a kol. (2013). Analýza a zdôvodnenie revízie Vzdelávacej oblasti Človek a svet práce. Učitel'ské noviny, LX (11), 25-27.

Kožuchová, M. (1993). Pracovná výchova a technické vzdelávanie na Ž̌. Bratislava: Univerzita Komenského.

Kožuchová, M., \& Pavelka, J. (2007). Požiadavky na vedecko-technickú gramotnost' absolventa základnej školy. In J. Maňák \& T. Janík, Absolvent základni školy(s. 168178). Brno: PdF MU.

Stebila, J. (2016). Aktuálne prístupy $\mathrm{k}$ inovatívnemu ponímaniu technického vzdelávania. Technika a vzdelávanie, 2016 (1), 47-50.

Sterry, L. (1987). A Relationship Between Technology Education and Trade and Instustrial Education. The Technology Teacher , 46 (5),

Lukáčová, D., \& Bánesz, G. (2007). Premeny technického vzdelávania. Nitra: PF UKF.

Ondrejkovič, P. (2003). Rola edukátora v súčasnej spoločnosti. Roly edukátora v meniacej sa spoločnosti - teoreticko-metodický seminár. Mladá Veda, 2017 (7), 13-24.

Pajtinka, L'. (2006). Učitelia patria do neba. Bratislava: IŠ-SET.

Samuhelová, M., \& Tokárová, M. (1996). Profesionálna etika a jej špecifiká v pedagogickej činnosti učitel'a. Pedagogické spektrum, 5 (6), 11-23.

ŠVP ISCED 2 . Štátny vzdelávací program pre druhý stupeň ZŠ (ISCED 2). Vzdelávacia oblast' Človek a svet práce. (2015).

ŠPÚ 2015. Inovovaný Štátny vzdelávací program. (2015).

Višňovský, L'., \& Kačáni, V. a kol. (2000). Základy školskej pedagogiky. Bratislava: Iris. 